\title{
Health and institutions in the post-pandemic
}

(DOlímpio / Nogueira V Bittar ${ }^{1}$

(iD) José Dínio Vaz Mendes ${ }^{1}$

1. Médico especialista em Saúde Pública, Secretaria de Estado da Saúde de São Paulo, São Paulo, SP, Brasil.

http://dx.doi.org/10.1590/1806-9282.66.9.1167

KEYWORDS: Coronavirus Infections. Pandemics. Health Facilities. Hospitals. Health Management.

PALAVRAS-CHAVE: Infecções por Coronavirus. Pandemias. Instalações de Saúde. Hospitais. Gestão em Saúde.

The post-COVID-19 period will bring political, social, economic, and geopolitical transformations; among these, those of occupational and behavioral nature will be prominent.

The healthcare industry suffers from the direct impacts of the pandemic and will continue to face problems: in the private sector, recession and unemployment will cause health insurance plans to lose beneficiaries and face financial balance problems.

In the public sector, SUS will suffer from a greater overload, with interruptions in routine care, the absorption of patients who lost their health insurance plans, a reduction in the public budgets and government funding capacity: survival will require reflections around the sustainability of the system and organizational changes in its institutions to increase their efficiency ${ }^{1}$.

In the $21^{\text {st }}$ century, with new scenarios, technological and management innovations, healthcare cannot maintain its archaic and slow structures and legal formats, with no updates to allow fast reactions and of suitable dimensions for problems, bringing peace to citizens and optimizing public spending ${ }^{2}$.

Among the issues that require modernization are the legal and administrative structures, such as the models of direct and indirect public administration.
Direct administration (DA) contemplates the management bodies (ministry and state and municipal health departments) and the state and municipal units providing healthcare services. Created in the 1930s based on models from European countries, this was particularly useful for the central administration government bodies, with professionalization and depoliticization of public actions. However, it is not a suitable model for health units that require agility in decision-making and administrative swiftness. Autonomy is extremely limited; the process of hiring a professional takes at least 134 days. Replacing a professional working on emergency units is disastrous. Third-party procurement and hiring do not take less than two months, which makes it difficult to meet demands in emergencies and even in routine. Purchases based exclusively on the lowest price to avoid problems can be a waste of resources when quality is ignored, particularly in healthcare, where there is a wide variety of innovative and high technology materials.

Slow administrative, operational, and technical actions are sources of waste of resources, the typical Brazilian hell: when there is a bed available, there is no professional, or there is a bed and a professional but no medicine or equipment, which in any case prevents services from being provided to the public. The 
frustration of professionals and administrators is huge and the fear of making emergency procurements and hirings, which will later be assessed by control bodies, also affects decision making. Low wages, too, make it more difficult to hire administrators.

Indirect administration unfolds into autarchy (some university hospitals), public legal foundations, mixed economy companies, and public companies. Created at the end of the 1960s to overcome the difficulties of $\mathrm{DA}$, it was increasingly restrained and, currently, it is almost as bad as the more traditional model for modern healthcare administration.

Two solutions were found for this problem in the State of São Paulo: the 'support foundations' (Philanthropic private legal foundation) and social healthcare organizations (Organizações Sociais de Saúde- OSS).

The foundations, created to support universities and specialized hospitals in the 1970s (40 years ago), promote operational agility, higher productivity, and quality in actions; however, they bring consequences such as the coexistence of two institutions for the same purpose as well as hiring personnel using different legal regimes (statutory and through the Brazilian Consolidation of Labor Laws - CLT), difficulties in establishing equal pay, and the possibility of different conflicts in the work environment ${ }^{3}$. However, they streamline operations, such as the hiring of personnel and procurement of materials and equipment, following regiments rigorously drawn based on the law and approved by control bodies. Without them, it would be impossible to provide assistance, research, and education.

The OSS, created in the 1990s (22 years ago), fully service the SUS, including hospitals, outpatient clinics, imaging, and logistics services, currently totaling 120 units managed by 31 organizations ${ }^{4}$. These are public services, contracted and regulated by DA, but with autonomy. Governed by their own legislation, they relate to the health departments through management contracts that specify the products to be delivered during a certain period. They have a personnel regulation that governs the recruitment, selection, admission, promotion, and dismissal of employees, and a procurement and hiring regulation that governs the acquisition of goods, execution of contracts, and other commitments, allowing for management governance and sustainability. They are periodically evaluated and remunerated according to the goals established and negotiated between the parties, based on the geographic, demographic, and epidemiological needs of each location and region. A secretary team is responsible for the management, and quarterly assessments are carried out by a commission formed by 10 internal and external members, including representatives of the Legislative Assembly, State Health Council, and recognized health professionals. The control bodies regularly evaluate the service operation and results.

One of the solutions to improve the administration of DA units is to transfer their management to the OSS, analyzing the convenience of such action on a case by case basis. An important point to make this kind of transformation viable is the existence and expansion of partners, preventing an excessive concentration of units in a few institutions, something that is not always true in all regions of the country, but which is more feasible in São Paulo. This is not simple, but it is possible.

Universities hospitals as autarchys deserve their own studies since their mission is beyond assistance but the basis for research and teaching, with institutional relations that require more complex organizational settings.

Health regulatory agencies are considered autarchy.

For managing bodies (DA), health ministry and departments, legal and operational solutions must be found so that they too can become agile in making the decisions that are of interest to the population, in the planning, coordination, and regulation of healthcare actions, including by strengthening units responsible for contract assessment. This implies the participation of the Legislative, Executive, and Judiciary powers and Civil Society.

Autonomy, with transparency, is the solution to deploy, with quality, policies that will result in healthcare programs and services, thus reducing the fragility of the system.

\section{REFERENCES}

1. Mendes JDV, Bittar OJNV. O SUS desconhecido. BEPA Bol Epidemiol Paul. 2017;14(165):21-3. [cited 2020 Jun 2]. Available from: http://portal.saude. sp.gov.br/resources/ccd/homepage/bepa/edicao-2017/edicao_165_-_ setembro_2.pdf

2. Bittar OJNV. Saúde e cenários em transição. BEPA Bol Epidemiol Paul. 2018;15(174):1-3. [cited 2020 /un 2]. Available from: http://sistema4.saude. sp.gov.br/sahe/documento/Saude_Cenarios\%20_em_Transicao.pdf

3. Grazzioli A. Fundações privadas: do poder à responsabilidade dos dirigentes [Dissertação]. São Paulo: Pontifícia Universidade Católica de São Paulo; 2011. [cited 2020 Jun 2]. Available from: https://tede2.pucsp.br/bitstream/ handle/5545/1/Airton\%20Grazzioli.pdf

4. Barbosa NB, Elias PEM. As organizações sociais de saúde como forma de gestão público/privado. Ciênc Saúde Coletiva. 2010;15(5):2483-95. 